\title{
Genetic Influence in Exercise Performance
}

\author{
Juan Del Coso ${ }^{1}$ (D) and Alejandro Lucia ${ }^{2,3,4, *}$ \\ 1 Centre for Sport Studies, Rey Juan Carlos University, 28943 Fuenlabrada, Spain; juan.delcoso@urjc.es \\ 2 Faculty of Sport Sciences, Universidad Europea de Madrid, 28670 Villaviciosa de Odón, Spain \\ Research Institute imas12, Hospital 12 de Octubre, 28041 Madrid, Spain \\ 4 Centro de Investigación Biomédica en Red de Fragilidad y Envejecimiento Saludable, 28029 Madrid, Spain \\ * Correspondence: alejandro.lucia@universidadeuropea.es
}

Citation: Del Coso, J.; Lucia, A. Genetic Influence in Exercise

Performance. Genes 2021, 12, 651.

https://doi.org/10.3390/

genes12050651

Received: 16 April 2021

Accepted: 19 April 2021

Published: 27 April 2021

Publisher's Note: MDPI stays neutral with regard to jurisdictional claims in published maps and institutional affiliations.

Copyright: (C) 2021 by the authors. Licensee MDPI, Basel, Switzerland. This article is an open access article distributed under the terms and conditions of the Creative Commons Attribution (CC BY) license (https:// creativecommons.org/licenses/by/ $4.0 /)$.
Numerous studies in the last two decades have analyzed the association between genetic variants and athletic performance, or other related traits (e.g., responses and adaptations to different exercise modalities or risk of sports injuries). However, the practical applicability of most findings in the field is still limited, with several caveats to consider. Notably, a deeper understanding is needed of potential gene-gene and gene-environment interactions. Future studies should also assess larger samples than in the past, as well as replication cohorts. This Special Issue, entitled Genetic Influence in Exercise Performance, includes five original investigations and three reviews that, we think, contribute to building evidence for the potential influence — or actual lack of effect—of some genetic factors on athletic performance.

Yvert and colleagues [1] investigate the individual and combined influence of polymorphisms in the peroxisome proliferator-activated receptor gamma coactivator 1 alpha (PPARGC1A) and nuclear respiratory factor 1 (NRF1) genes (rs8192678 and rs6949152, respectively) on the muscle fiber composition of healthy individuals. PPARGC1A (commonly known as PGC1 $\alpha$ ) is a central inducer of mitochondrial biogenesis and function [2]. Previous studies have reported a higher frequency of the rs8192678 G/G genotype in endurance athletes than in their nonathletic controls, suggesting that this genotype might be associated with aerobic performance [3-6]. In turn, NFR1 is a target of PGC1 $\alpha$ whose association with endurance performance has been less studied [7]. In the investigation by Yvert et al. [1], these two polymorphisms were not associated with muscle fiber type distribution-as assessed by the proportion of myosin heavy-chain isoforms-in the vastus lateralis of healthy men. Yet, in women, rs8192678 A/A and rs6949152 A/A genotypes showed a link-individually or in combination-with a higher and lower of proportion of I and IIx isoforms, respectively. This investigation suggests that the potential influence of both PPARGC1A and NRF1 genes on endurance performance might be mediated by an effect on muscle fiber differentiation, at least in women.

Muñoz and colleagues [8] study the influence of the cytochrome P450 family 1 subfamily A member 2 (CYP1A2) rs762551 and adenosine A2A receptor (ADORA2A) rs5751876 polymorphisms on the ergogenic effect of acute caffeine intake in professional handball players. The CYP1A2 enzyme is responsible for $~ 95 \%$ of caffeine metabolism, and individuals with the rs762551 A/A genotype are categorized as "fast metabolizers" because they usually show a higher rate of caffeine metabolization into paraxanthine than their referents with the C-allele [9]. There is also rationale to support a role for the ADORA2A gene because a major mechanism explaining the potential ergogenic effect of caffeine at the brain level is a blockade of the receptors for an inhibitory neurotransmitter, adenosine, thereby increasing arousal [10]. In this context, $A D O R A 2 A \mathrm{~T} / \mathrm{T}$ are potentially "high-responders" to caffeine compared to those with the C-allele [11]. Although both CYPA1A2 A/A [12] and $A D O R A 2 A \mathrm{~T} / \mathrm{T}$ [13] individuals might show a higher ergogenic effect of caffeine ingestion than those with the $\mathrm{C}$-allele, the potential influence of these gene variants is rather small [14-17]. In the Muñoz et al. study [8], the neuromuscular performance of 
handball players increased with the intake of $3 \mathrm{mg} / \mathrm{kg}$ of caffeine, irrespective of CYPA1A2 and $A D O R A 2 A$ genotype. Thus, this investigation contributes to the body of knowledge on the ergogenic effect of caffeine on sports performance in real sport scenarios, and it does not support a role for CYPA1A2 or ADORA2A genetic variants. In this regard, we suggest that, although they might appear less attractive or even less publishable, "negative" findings are as important as positive ones in order to build a balanced perspective of the scientific evidence. If only "positive" findings were to be published, we would only see the tip of the iceberg in the nurture vs. nature debate.

Lulińska and colleagues [18] study the association of variants in several matrix metalloproteinases (MMP)-encoding genes (MMP1 rs1799750, MMP10 (rs486055) and MMP12 (rs2276109)) and the risk of an important injury in the context of sports-non-contact anterior cruciate ligament (ACL) rupture. These authors address a relevant question. Indeed, the prevention of ACL injuries is essential, given the long time lost for competition, the long-term consequences on articular cartilage, even in surgically treated injuries, and the resulting high economic costs [19]. MMPs play an essential role in the homeostasis of the extracellular matrix (ECM) of connective tissue [20], as these enzymes digest collagen and other structural molecules within ECM [21], with genetic MMP gene variants potentially affecting the capacity of connective tissue to bear mechanical force due to excessive collagen degradation. For instance, it has been previously reported that the rs2276109 A/A genotype might be associated with a higher risk of non-contact ACL rupture [22], with some interactions reported for the genes encoding the different types of collagen in the context of ACL rupture risk [23,24]. However, Lulińska et al. report no association of the aforementioned $M P P$ variants with non-contact $A C L$ rupture when comparing genotype distributions in individuals with primary non-contact ACL rupture vs. their referents without any history of this condition. Thus, their findings do not support the use of genetic screening among athletes to prevent ACL rupture (i.e., by identifying potential "high-risk" athletes), which is in line with recent research [25].

Leońska-Duniec and colleagues [26] investigate the potential influence of the c.34C/T polymorphism (rs17602729) in the gene that codifies the skeletal-muscle isoform of adenosine monophosphate deaminase (AMPD1) on the effects of a 12-week aerobic training program in obesity related parameters among healthy women. This enzyme plays an important regulatory role in muscle metabolism by catalyzing the deamination of adenosine monophosphate (AMP) to inosine monophosphate (IMP) and shifting the reaction towards ATP resynthesis in muscles. In fact, the aforementioned polymorphism has been previously linked with endurance performance, with the $C / C$ genotype associated with a higher likelihood of being an elite endurance athlete vs. carriage of the mutant T-allele $[4,27,28]$. Additionally, $\mathrm{T} / \mathrm{T}$ and $\mathrm{C} / \mathrm{T}$ individuals might show a significantly lower relative increase in cardiorespiratory fitness (peak oxygen uptake, $\mathrm{VO}_{2 \text { peak }}$ ) after three months of training compared to their C/C counterparts [29], which is in overall agreement with a previous report from the classic HERITAGE Family study reporting a lower trainability of aerobic fitness in T/T individuals compared to the two other genotypes [30]. Interestingly, although the underlying mechanisms remain to be elucidated, there is preliminary evidence for a certain role of the c.34C/T variation in cardiometabolic traits [31]. In the Leońska-Duniec et al. study [26], a 12-week training program proved effective in producing a significant loss of body mass and relative fat mass while increasing fat-free mass and high-density lipoprotein cholesterol, as well as improving glucose control. However, these benefits were of similar magnitude irrespective of c.34C/T genotype. These results suggest that the $\mathrm{T}$ allele in the c.34C/T polymorphism does not influence exercise training responses with regard to body composition and metabolic parameters, at least in healthy women.

Determining the potential influence of genetic factors on $\mathrm{VO}_{2 \text { peak }}$ is of medical relevance given the strong, independent, and predictive value of this variable with regard to cardiovascular risk and mortality. A seminal study by Claude Bouchard and colleagues found comparable $\mathrm{VO}_{2 \text { peak }}$ values in brothers of the same sibship, and the similarities in $\mathrm{VO}_{2 \text { peak }}$ were even greater in dizygotic and monozygotic twins [32], with the authors 
suggesting that the genetic effect on $\mathrm{VO}_{2 \text { peak }}$ reached $\sim 40 \%$. In this issue of the journal, Gaowa and colleagues [33] study the influence of several candidate genetic variants in $\mathrm{VO}_{2 \text { peak }}$ among 1000 untrained Han Chinese people, with a similar representation of both sexes. When setting a stringent threshold p-value of 0.0004 , only one single nucleotide polymorphism (rs4295), located in the gene encoding angiotensin-converting enzyme, was associated with $\mathrm{VO}_{2 \text { peak }}$. Furthermore, from a list of 125 candidate variants showing previous evidence for an association with exercise or cardiovascular traits, only three ( $\mathrm{rs} 4295=1.1 \%$, angiotensin II receptor type $1 \mathrm{rs} 275652=0.6 \%$, and myostatin rs7570532 $=0.5 \%)$ accounted together for just $2.2 \%(p=0.0007)$ of the interindividual variance in $\mathrm{VO}_{2 \text { peak. }}$. The authors conclude that a strong independent health indicator, such as cardiorespiratory fitness, might be influenced by several polymorphic variations in candidate genes (at least in the pre-trained state), but these polymorphisms represent a minor portion of the variance, suggesting a more important role for environmental factors. An important novelty of this study is the ethnic origin of the population, as the bulk of the evidence on genetics and exercise-related traits comes from research conducted in Caucasian people, and these findings might not be extrapolated to other ethnicities.

There are three high-quality reviews in this Special Issue. Kitazawa and coworkers [34] discuss the importance of central nervous system (CNS)-related genes and athletic performance. These authors neatly review the role of some CNS areas and functions related to a predisposition to inherent exercise capacity, such as the pain analgesia system, the dopaminergic and serotonergic systems, neuronal circuits related to neuroplasticity, and thermoregulation-related factors. This review also focuses on CNS-related variants that might be involved in exercise capacity, such as those related to the serotonergic system, as well as the GABAergic, glutamatergic, dopaminergic, or noradrenergic systems (e.g., the fifth Ewing variant (FEV) in the serotonergic system, D2 receptor (DRD2) and catechol-Omethyltransferase (COMT) in the dopaminergic system, and potentially transcranial direct current stimulation tDCS-responsive genes in the GABAergic system). Future research ideas are also discussed. On the other hand, Hall et al., [35] propose a novel contextual framework in sports sciences-the use of chromosome conformation signature (CCS). CCS refers to the organization of the human genome within three-dimensional space, which has recently emerged as a dynamic epigenetic regulator of gene expression. In this interesting review, the authors also show examples of how CCS data may help to explain interindividual differences in response to exercise or nutritional interventions, and could also be helpful for potential doping detection. Finally, Pickering et al., [36] discuss why it is still too early to use genetic information for talent detection in sports based on scientific evidence; this is despite the dozens of commercially available genetic tests that are purported to predict sports performance. Other tools (e.g., "genotype scores") are also proposed to help identify those individuals who might be inherently predisposed to succeed in sport.

Although the field of sports genetics is fascinating, the task of identifying "the champions' genes" is a very difficult one. Much more research is needed before genetic screening becomes a useful tool in the context of personalized exercise training for disease treatment or prevention.

Funding: This research received no external funding.

Conflicts of Interest: The authors declare no conflict of interest.

\section{References}

1. Yvert, T.; Miyamoto-Mikami, E.; Tobina, T.; Shiose, K.; Kakigi, R.; Tsuzuki, T.; Takaragawa, M.; Ichinoseki-Sekine, N.; Pérez, M.; Kobayashi, H.; et al. PPARGC1A rs8192678 and NRF1 rs6949152 polymorphisms are associated with muscle fiber composition in women. Genes 2020, 11, 1012. [CrossRef]

2. Austin, S.; St-Pierre, J. PGC1 $\alpha$ and mitochondrial metabolism-Emerging concepts and relevance in ageing and neurodegenerative disorders. J. Cell Sci. 2012, 125, 4963-4971. [CrossRef]

3. Chen, Y.; Wang, D.; Yan, P.; Yan, S.; Chang, Q.; Cheng, Z. Meta-analyses of the association between the PPARGC1A Gly482Ser polymorphism and athletic performance. Biol. Sport 2019, 36, 301-309. [CrossRef] [PubMed] 
4. Varillas Delgado, D.; Orriols, J.J.T.; Monge Martín, D.; Del Coso, J. Genotype scores in energy and iron-metabolising genes are higher in elite endurance athletes than in nonathlete controls. Appl. Physiol. Nutr. Metab. 2020, 45, 1225-1231. [CrossRef]

5. Petr, M.; Maciejewska-Skrendo, A.; Zajac, A.; Chycki, J.; Stastny, P. Association of elite sports status with gene variants of peroxisome proliferator activated receptors and their transcriptional coactivator. Int. J. Mol. Sci. 2020, 21, 162. [CrossRef]

6. Lucia, A.; Gómez-Gallego, F.; Barroso, I.; Rabadán, M.; Bandrés, F.; San Juan, A.F.; Chicharro, J.L.; Ekelund, U.; Brage, S.; Earnest, C.P.; et al. PPARGC1A genotype (Gly482Ser) predicts exceptional endurance capacity in European men. J. Appl. Physiol. 2005, 99, 344-348. [CrossRef]

7. He, Z.; Hu, Y.; Feng, L.; Li, Y.; Liu, G.; Xi, Y.; Wen, L.; Lucia, A. NRF-1 genotypes and endurance exercise capacity in young Chinese men. Br. J. Sports Med. 2008, 42, 361-366. [CrossRef] [PubMed]

8. Muñoz, A.; López-Samanes, Á.; Aguilar-Navarro, M.; Varillas-Delgado, D.; Rivilla-García, J.; Moreno-Pérez, V.; Del Coso, J. Effects of CYP1A2 and ADORA2A Genotypes on the Ergogenic Response to Caffeine in Professional Handball Players. Genes 2020, 11, 933. [CrossRef] [PubMed]

9. Sachse, C.; Brockmöller, J.; Bauer, S.; Roots, I. Functional significance of a C $\rightarrow$ A polymorphism in intron I of the cytochrome P450 CYP1A2 gene tested with caffeine. Br. J. Clin. Pharmacol. 1999. [CrossRef] [PubMed]

10. Davis, J.M.; Zhao, Z.; Stock, H.S.; Mehl, K.A.; Buggy, J.; Hand, G.A. Central nervous system effects of caffeine and adenosine on fatigue. Am. J. Physiol. Integr. Comp. Physiol. 2003, 284, R399-R404. [CrossRef] [PubMed]

11. Alsene, K.; Deckert, J.; Sand, P.; De Wit, H. Association between A2a receptor gene polymorphisms and caffeine-induced anxiety. Neuropsychopharmacology 2003, 28, 1694-1702. [CrossRef]

12. Guest, N.; Corey, P.; Vescovi, J.; El-Sohemy, A. Caffeine, CYP1A2 genotype, and endurance performance in athletes. Med. Sci. Sports Exerc. 2018, 50, 1570-1578. [CrossRef]

13. Loy, B.D.; O'Connor, P.J.; Lindheimer, J.B.; Covert, S.F. Caffeine Is Ergogenic for Adenosine $\mathrm{A}_{2 \mathrm{~A}}$ Receptor Gene (ADORA2A) T Allele Homozygotes: A Pilot Study. J. Caffeine Res. 2015, 5, 73-81. [CrossRef]

14. Puente, C.; Abián-Vicén, J.; Coso, J.D.; Lara, B.; Salinero, J.J. The CYP1A2 -163C>A polymorphism does not alter the effects of caffeine on basketball performance. PLoS ONE 2018, 13, e0195943. [CrossRef] [PubMed]

15. Carswell, A.T.; Howland, K.; Martinez-Gonzalez, B.; Baron, P.; Davison, G. The effect of caffeine on cognitive performance is influenced by CYP1A2 but not ADORA2A genotype, yet neither genotype affects exercise performance in healthy adults. Eur. J. Appl. Physiol. 2020, 120, 1495-1508. [CrossRef] [PubMed]

16. Spineli, H.; Pinto, M.P.; Dos Santos, B.P.; Lima-Silva, A.E.; Bertuzzi, R.; Gitaí, D.L.G.; de Araujo, G.G. Caffeine improves various aspects of athletic performance in adolescents independent of their 163 C > A CYP1A2 genotypes. Scand. J. Med. Sci. Sport. 2020, 30, 1869-1877. [CrossRef] [PubMed]

17. Salinero, J.J.; Lara, B.; Ruiz-Vicente, D.; Areces, F.; Puente-Torres, C.; Gallo-Salazar, C.; Pascual, T.; Del Coso, J. CYP1A2 genotype variations do not modify the benefits and drawbacks of caffeine during exercise: A pilot study. Nutrients 2017, 9, 269. [CrossRef] [PubMed]

18. Lulińska, E.; Gibbon, A.; Kaczmarczyk, M.; Maciejewska-skrendo, A.; Ficek, K.; Leońska-Duniec, A.; Wilk, M.; Leźnicka, K.; Michałowska-Sawczyn, M.; Humińska-Lisowska, K.; et al. Matrix metalloproteinase genes (Mmp1, mmp10, mmp12) on chromosome 11q22 and the risk of non- contact anterior cruciate ligament ruptures. Genes 2020, 11, 766. [CrossRef]

19. Alentorn-Geli, E.; Mendiguchía, J.; Samuelsson, K.; Musahl, V.; Karlsson, J.; Cugat, R.; Myer, G.D. Prevention of non-contact anterior cruciate ligament injuries in sports. Part II: Systematic review of the effectiveness of prevention programmes in male athletes. Knee Surg. Sports Traumatol. Arthrosc. 2014, 22, 16-25. [CrossRef] [PubMed]

20. Malila, S.; Yuktanandana, P.; Saowaprut, S.; Jiamjarasrangsi, W.; Honsawek, S. Association between matrix metalloproteinase-3 polymorphism and anterior cruciate ligament ruptures. Genet. Mol. Res. 2011, 10, 4158-4165. [CrossRef] [PubMed]

21. Davis, M.E.; Gumucio, J.P.; Sugg, K.B.; Bedi, A.; Mendias, C.L. MMP inhibition as a potential method to augment the healing of skeletal muscle and tendon extracellular matrix. J. Appl. Physiol. 2013, 115, 884-891. [CrossRef]

22. Posthumus, M.; Collins, M.; van der Merwe, L.; O'Cuinneagain, D.; van der Merwe, W.; Ribbans, W.J.; Schwellnus, M.P.; Raleigh, S.M. Matrix metalloproteinase genes on chromosome 11q22 and the risk of anterior cruciate ligament (ACL) rupture. Scand. J. Med. Sci. Sport 2012, 22, 523-533. [CrossRef]

23. Zhao, D.; Zhang, Q.; Lu, Q.; Hong, C.; Luo, T.; Duan, Q.; Shu, S.; Lv, J.; Zhao, W. Correlations between the genetic variations in the COL1A1, COL5A1, COL12A1, and b-fibrinogen genes and anterior cruciate ligament injury in Chinese patients. J. Athlet. Train. 2020, 55, 515-521. [CrossRef] [PubMed]

24. O'Connell, K.; Knight, H.; Ficek, K.; Leonska-Duniec, A.; Maciejewska-Karlowska, A.; Sawczuk, M.; Stepien-Slodkowska, M.; O'Cuinneagain, D.; van der Merwe, W.; Posthumus, M.; et al. Interactions between collagen gene variants and risk of anterior cruciate ligament rupture. Eur. J. Sport Sci. 2015, 15, 341-350. [CrossRef] [PubMed]

25. Sivertsen, E.A.; Haug, K.B.F.; Kristianslund, E.K.; Trøseid, A.M.S.; Parkkari, J.; Lehtimäki, T.; Mononen, N.; Pasanen, K.; Bahr, R. No Association Between Risk of Anterior Cruciate Ligament Rupture and Selected Candidate Collagen Gene Variants in Female Elite Athletes From High-Risk Team Sports. Am. J. Sports Med. 2019, 47, 52-58. [CrossRef]

26. Leońska-Duniec, A.; Maculewicz, E.; Humińska-Lisowska, K.; Maciejewska-Skrendo, A.; Leźnicka, K.; Cięszczyk, P.; Sawczuk, M.; Trybek, G.; Wilk, M.; Lepionka, W.; et al. AMPD1 C34T polymorphism (RS17602729) is not associated with post-exercise changes of body weight, body composition, and biochemical parameters in Caucasian females. Genes 2020, 11, 558. [CrossRef] [PubMed] 
27. Cięszczyk, P.; Eider, J.; Ostanek, M.; Leoska-Duniec, A.; Ficek, K.; Kotarska, K.; Girdauskas, G. Is the C34T polymorphism of the AMPD1 gene associated with athlete performance in rowing? Int. J. Sports Med. 2011, 32, 987-991. [CrossRef]

28. Rubio, J.C.; Martín, M.A.; Rabadán, M.; Gómez-Gallego, F.; San Juan, A.F.; Alonso, J.M.; Chicharro, J.L.; Pérez, M.; Arenas, J.; Lucia, A. Frequency of the C34T mutation of the AMPD1 gene in world-class endurance athletes: Does this mutation impair performance? J. Appl. Physiol. 2005, 98, 2108-2112. [CrossRef]

29. Thomaes, T.; Thomis, M.; Onkelinx, S.; Fagard, R.; Matthijs, G.; Buys, R.; Schepers, D.; Cornelissen, V.; Vanhees, L. A genetic predisposition score for muscular endophenotypes predicts the increase in aerobic power after training: The CAREGENE study. BMC Genet. 2011, 12, 84. [CrossRef]

30. Rico-Sanz, J.; Rankinen, T.; Joanisse, D.R.; Leon, A.S.; Skinner, J.S.; Wilmore, J.H.; Rao, D.C.; Bouchard, C. Associations between cardiorespiratory responses to exercise and the C34T AMPD1 gene polymorphism in the HERITAGE Family study. Physiol. Genom. 2003, 14, 161-166. [CrossRef]

31. Safranow, K.; Czyzycka, E.; Binczak-Kuleta, A.; Rzeuski, R.; Skowronek, J.; Wojtarowicz, A.; Jakubowska, K.; Olszewska, M.; Loniewska, B.; Kaliszczak, R.; et al. Association of C34T AMPD1 gene polymorphism with features of metabolic syndrome in patients with coronary artery disease or heart failure. Scand. J. Clin. Lab. Investig. 2009, 69, 102-112. [CrossRef] [PubMed]

32. Bouchard, C.; Lesage, R.; Lortie, G.; Simoneau, J.A.; Hamel, P.; Boulay, M.R.; Pérusse, L.; Thériault, G.; Leblanc, C. Aerobic performance in brothers, dizygotic and monozygotic twins. Med. Sci. Sports Exerc. 1986, 18, 639-646. [CrossRef] [PubMed]

33. Del Coso, J.; Del Coso, J.; Gu, Z.; Gerile, W.; Yang, R.; Díaz-Peña, R.; Valenzuela, P.L.; Lucia, A.; He, Z. Interindividual variation in cardiorespiratory fitness: A candidate gene study in han Chinese people. Genes 2020, 11, 555. [CrossRef]

34. Kitazawa, H.; Hasegawa, K.; Aruga, D.; Tanaka, M. Potential Genetic Contributions of the Central Nervous System to a Predisposition to Elite Athletic Traits: State-of-the-Art and Future Perspectives. Genes 2021, 12, 371. [CrossRef]

35. Hall, E.C.R.; Murgatroyd, C.; Stebbings, G.K.; Cunniffe, B.; Harle, L.; Salter, M.; Ramadass, A.; Westra, J.W.; Hunter, E.; Akoulitchev, A.; et al. The prospective study of epigenetic regulatory profiles in sport and exercise monitored through chromosome conformation signatures. Genes 2020, 11, 905. [CrossRef] [PubMed]

36. Pickering, C.; Kiely, J.; Grgic, J.; Lucia, A.; Del Coso, J. Can Genetic Testing Identify Talent for Sport? Genes $2019,10,972$. [CrossRef] [PubMed] 